\title{
OXYCHILUS (MEDITERRANEA) HYDATINUS (GASTROPODA: ZONITIDAE) NEW FOR SLOVAKIA, WITH NOTES ON ITS DISTRIBUTION IN HUNGARY
}

\author{
LiBOR DVOŘÁK ${ }^{1}$, MichAL HORSÁK ${ }^{2}$ \& ANDRÁS VARGA ${ }^{3}$ \\ ${ }^{1}$ Šumava National Park and PLA Administration, Sušická 399, CZ-34192 Kašperské Hory, Czech Republic \\ (e-mail: libor.dvorak@npsumava.cz) \\ ${ }^{2}$ Masaryk University, Faculty of Science, Department of Zoology and Ecology, Kotlářská 2, CZ-61137 Brno, \\ Czech Republic (e-mail: horsak@sci.muni.cz) \\ ${ }^{3}$ Mátra Múzeum, Kossuth út 40,H-3200 Gyöngyös, Hungary (e-mail: avarga.2@dpq.hu)
}

ABSTRACT: The first records of Oxychilus hydatinus (Rossmässler, 1838) from Slovakia are reported. The material was identified based on a detailed comparative study of shell morphology and internal structure of penis. The Slovak sites represent the northernmost occurrence of this species.

KEY WORDS: Gastropoda, Oxychilus hydatinus, Slovakia, first records

\section{INTRODUCTION}

During malacological research concerning cemeteries in Bratislava and the surrounding villages (SW Slovakia), three interesting specimens of the genus Oxychilus Fitzinger, 1833 were found in two sites.

O. (Mediterranea) hydatinus (Rossmässler, 1838) is a circum-Mediterranean species, distributed from the Canary Islands to as far as Asia Minor and the Crimea, reaching Romania and Hungary (RIEDEL 1992). O. (M.) inopinatus (Uličný, 1887) is a sub-Carpathian-Balkan species, distributed from Austria, Central Poland and Ukraine to southern Bulgaria and northern Greece (RIEDEL 1992). The two species are rather similar in their shell appearance but they are regarded as distinct taxa (RIEDEL 1969, 1980). Moreover, there are no relevant differences in the genital morphology between $O$. hydatinus and $O$. inopinatus (RIEDEL 1969: Figs 8-11; GIUSTI et al. 1985: Fig. 2). However, obvious differences are found in the internal structure of the penis (RIEDEL 1959).

\section{MATERIAL EXAMINED AND SHELL DESCRIPTION}

1. SW Slovakia, Bratislava city, Ondřejský Cintorín cemetery $\left(48^{\circ} 08^{\prime} 47^{\prime \prime} \mathrm{N}, 17^{\circ} 07^{\prime} 30^{\prime \prime} \mathrm{E}\right.$ ) (grid reference databank of Fauna of Slovakia $=7868 d$ ), on the soil surface under the remains of roof covering, $120 \mathrm{~m}$ a.s.l., 3.12.2002, 7.10.2003, L. DVOŘÁK \& T. ČEJKA lgt.

2. SW Slovakia, Kalinkovo village, cemetery (4804'02" N, 17²15'00” E) (7969b), under a plank deeply embedded in the soil, $128 \mathrm{~m}$ a.s.l., 8.10.2003, L. DVOř́́K lgt.
The shells are small (up to $4 \mathrm{~mm}$ width), shiny, white-yellowish in colour, rather depressed, convex above. The spire is formed by 4 whorls (two adult specimens), regularly and progressively increasing, the body whorl only slightly wider than the penultimate; umbilicus small, ca 1/9 shell maximum diameter, so that the preceding whorl is visible in umbilicus (Figs 1-2). 


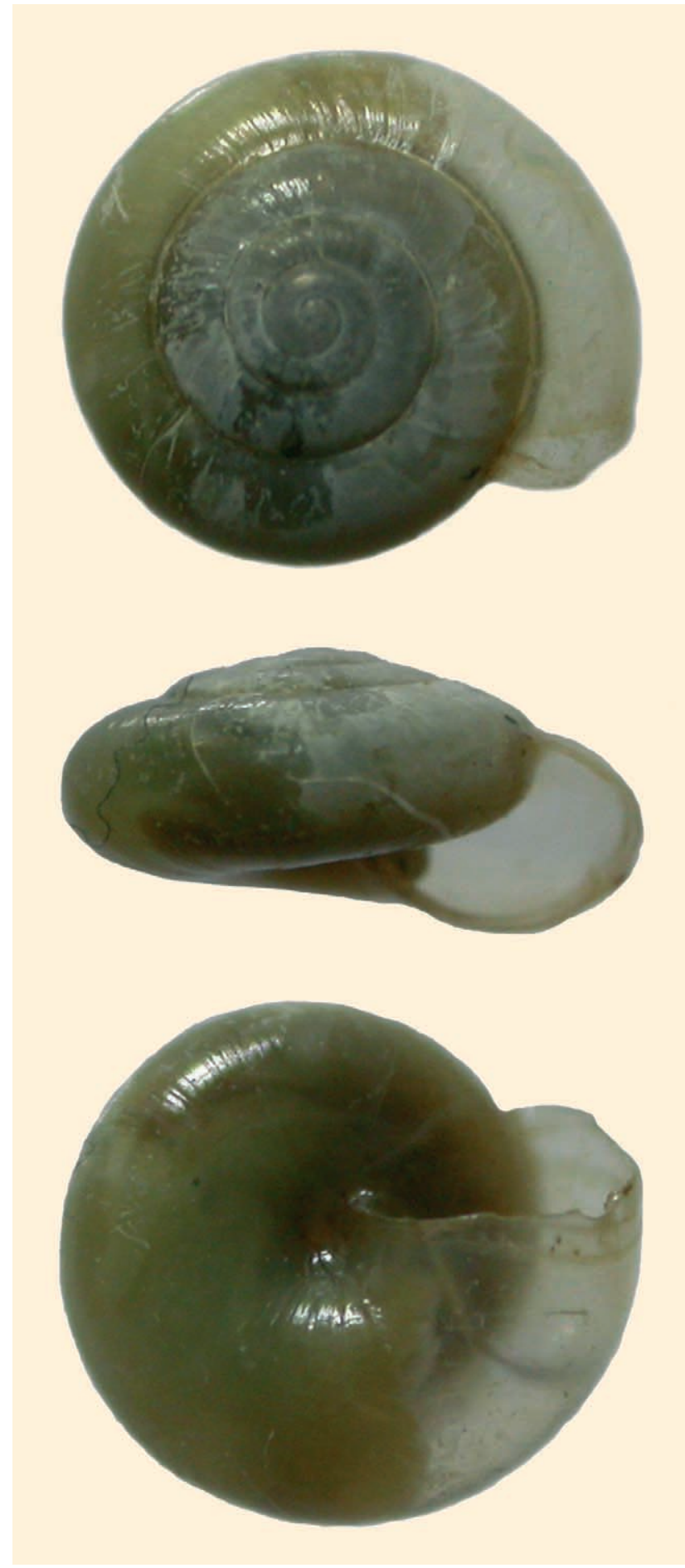

Fig. 1. Shell of Oxychilus hydatinus from Ondřejský Cintorín cemetery. Photo: M. HORSÁK

\section{RESULTS}

Our comparative study on the shell morphology reveals constant differences between the two mentioned Oxychilus species. The shell of $O$. inopinatus has a flattish spire, narrowed umbilicus and a wider body

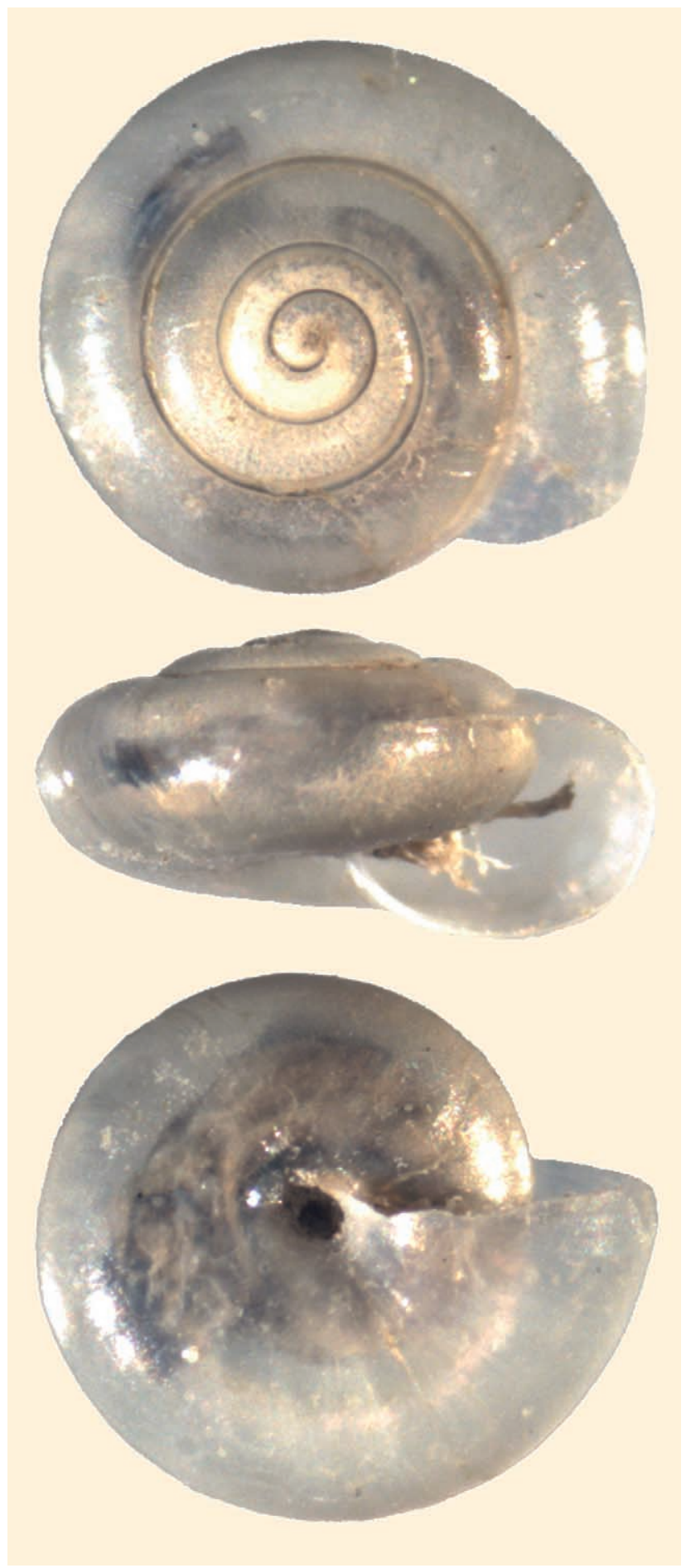

Fig. 2. Shell of Oxychilus hydatinus from the cemetery in Kalinkovo. Photo: M. HORSÁK

whorl (mean width ratio of the last and penultimate whorl is about 1.8:1). O. hydatinus has a higher spire, more widely open umbilicus and a narrower body whorl (mean width ratio of the last and penultimate 
whorl is about 1.1-1.2:1). A. RIEDEL (pers. comm.) found out the same differences as well.

The identification based on shell morphology (which indicates that our specimens are O. hydatinus, not $O$. inopinatus) was confirmed by the internal structure of penis (cf. Fig. 3 in this paper and Fig. 2 in RIEDEL 1959).

Based on the discussed characters we consider the specimens from Bratislava and Kalinkovo to represent $O$. hydatinus (for comparison see the Corsican $O$. hydatinus on plate 2A in GIUSTI et al. 1985 or Hungarian specimen in KOVÁCS 1980).

\section{DISTRIBUTION IN SLOVAKIA AND HUNGARY}

O. (M.) hydatinus - a circum-Mediterranean species - was recorded from the area between the Canary Islands in the west and Asia Minor and Crimea in the east. The northernmost localities were known from Hungary. The first records of $O$. hydatinus from Hungary were from Békécsaba in SE Hungary (KOVÁCS 1974, 1980, PINTÉR 1975, PINTÉR et al. 1979). Other authors studied its distribution in that region (DOMOKOS \& KOVÁCS 1988). Later, the species was found in Szársomlyó in the south of Hungary (SUARA 1981). Further data from other Hungarian regions followed: GEBHARDT's revised find from Pécs, 1954 (VARGA 1988); several localities in the Villány Hills (VARGA et al. 2000, FEHÉR \& GUBÁNYI 2001) and Somogy county (HÉRA \& VARGA 2001).

Several collections in Hungary contain additional specimens from the following localities:

Collection of the Mátra Muzeum, Gyöngyös: 1. Beremend, along the way to the quarry, 13.VIII.1987, A. VARGA lgt. et det. (Hungarian grid system: CR07). 2. Drávasztára-Zaláta, 2.X.1958, A. GEBHARDT lgt., A. VARGA det. (YL27). 3. Baranyahídvég, drift of the brook, 18.III.1999, Á. UHERKOVICH lgt., A. VARGA det. (BR67).

Collection of Á. UHERKOVICH, Pécs: 4. Szentdénes, drift of the Bükkösdi brook, 14.III.2000, Á. UHERKOVICH lgt. et det. (YL29).

Collection of Somogy Megyei Múzeum, Kaposvár: 5. Kaposvár, Töröcske park-forest, 2000, Z. HÉRA leg. et det. (YM13).

The Hungarian localities form two isolated clusters. One is located east of the Danube River, in the settlement of Békéscsaba, on the joint of four squares of the UTM grid map. West of the River Danube, several localities of $O$. hydatinus are scattered in the south-western part of the country, including the Villány Hills, Zselic, Mecsek Mts. and the surroundings. It occurs in both natural (predominantly on limestone) and secondary habitats. All the localities are situated, like in Slovakia, at low altitudes, between 100 and $200 \mathrm{~m}$ a.s.l.
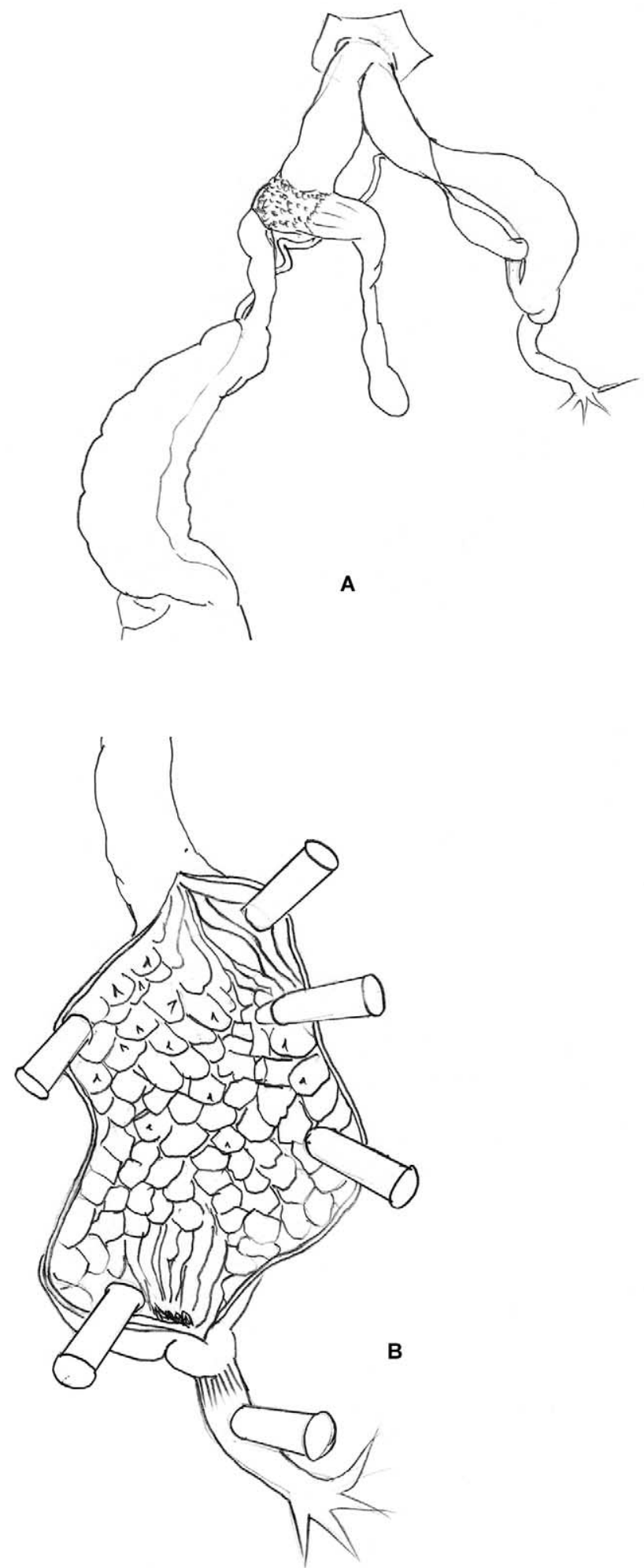

Fig. 3. Genitalia of Oxychilus hydatinus from Ondřejský Cintorín cemetery. Drawing: F. Giusti. a - external morphology, b - internal structure

In relation to the Hungarian localities, the Slovak records considerably extend the distribution area of $O$. hydatinus to the north. The present distribution in Slovakia and Hungary is shown in Fig. 4. Thus yet an- 
other species must be added to the check-list of Slovak molluscs.

It should be remembered that the scanty material (so far three individuals) cannot reflect the entire variability of Slovakian populations. Without final solution is also the problem of possible synonymy between the two Mediterranea species mentioned above, which was pointed out by GIUSTI et al. (1985).

\section{ACKNOWLEDGEMENTS}

The authors would like to express their thanks to Prof. Folco GIUSTI (Universita Degli Studi di Siena, Italy) for the anatomical determination of the specimens and very valuable comments on the manuscript. We are grateful Eng. TOMÁŠ ČEJKA (Slovak Academy of Sciences, Bratislava, Slovakia) for his help in the field and for the precise localisation of Slovakian cemeteries. The work was partly funded by the grant from the Czech Ministry of Education No. MSM 14310010.

\section{REFERENCES}

Domokos T., KovÁcs GY. 1988. A Békéscsabai Széchenyi-liget Mollusca-faunájáról. (Helicodiscus singleyanus, Vitrea contracta, Oxychilus hydatinus együttes elófordulása). Malakológiai Tájékoztató 8: 15-25.

FEHÉR Z., GUBÁNYI A. 2001. A magyarországi puhatestúek elterjedése. Az MTM puhatestú-gyứjteményének katalógusa. Magyar Természettudományi Múzeum, Budapest, 466 pp.

GiUsti F., HolyoaK D. T., MANGANelli G. 1985. Oxychilus (Ortizius?) clarus (Held) on Corsica and new data on the systematic position of Helix hydatina Rossmässler (Pulmonata: Zonitidae). J. Conch. 32: 17-24.

HérA Z., VARGA A. 2001. Somogy megye puhatestú (Mollusca) faunája [Mollusc fauna of Somogy county (Mollusca) ]. Natura Somogyiensis 1: 29-40.

Kerney M. P., Cameron R. A. D., Jungbluth J. H. 1983. Die Landschnecken Nord- und Mitteleuropas. Verlag Paul Parey, Hamburg und Berlin.

KovÁCS GY. 1974. [Die malakofauna von Békécsaba und Umgebung]. Álattani Közlemények 61: 35-41.

KOVÁCS GY. 1980. [Grundzüge der Molluskenfauna des Bezirkes Békés]. A Békés Megyei Múzeumok Közleményei 6: 51-84.

PINTÉR L. 1975. Die Oxychilini Ungarns (Gastropodoa: Zonitidae). Folia Hist. Nat. Mus. Matr. 3: 125-38.

Pintér L., RichnovszkY A., Szigethy A. 1979. A magyarországi recens puhatestúek elterjedése. Soosiana, Suppl. I: I-VI + 1-351.

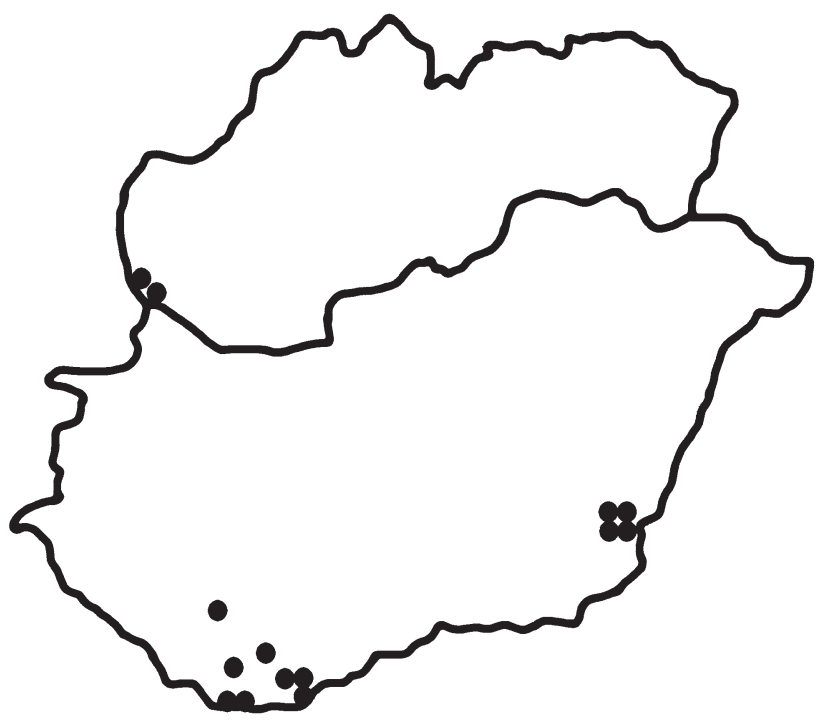

Fig. 4. Present distribution of Oxychilus hydatinus in Slovakia and Hungary

RIEDEL A. 1959. Materialen zur Kenntnis der paläarktische Zonitidae (Gastropoda). V-VI. Ann. Zool. 18: 179-188.

RiEDEL A. 1969. Die Untergattungen Morlina A.J. Wagner und Riedelius Hudec der Gattung Oxychilus Fitzinger (Gastropoda, Zonitidae). Ann. Zool. 27: 91-131.

Riedel A. 1980. Genera Zonitidarum. W. Backhuys Publ., Rotterdam.

RIEDEL A. 1992. The Zonitidae (sensu lato) (Gastropoda, Pulmonata) of Greece. Fauna Graeciae, 5. Hellenic Zoological Society, Athens.

SUARA R. 1981. [Neuer Fundort von Oxychilus hydatinus (Rossm.) in Ungarn]. Soosiana 9: 25-26.

VARGA A. 1988. Gebhardt Antal recens malakológiai anyagának revíziója - Revision of A. Gebhardt's recent malacological collection. Jan. Pan. Múz. Évk. 33: 53-66.

VArga A., Uherkovich Á., Sólymos P. 2000. A Villányi-hegység és környéke malakofaunisztikai vizsgálatának eddigi eredményei (Mollusca). In: The Flora, Vegetation and Fauna of the Villány Hills, South Hungary (Uherkovich Á., ed.), Studia Pannonica (A) Series Historico-Naturalis 10: 89-110.

Received: May 18th, 2004 Accepted: July 5th, 2004 